\title{
FERTILIZING CAPACITY OF EPIDIDYMAL SPERMATOZOA
}

\author{
J. W. OVERSTREET \\ A.R.C. Unit of Reproductive Physiology and Biochemistry,* \\ University of Cambridge
}

(Received 27th Fanuary 1969)

\begin{abstract}
Summary. When does were inseminated with spermatozoa from the lower part of the corpus epididymidis of individual bucks, fertilization rates varied greatly and in almost every case, cleavage occurred later than has been reported following the insemination of ejaculated spermatozoa. The retardation occurred both when spermatozoa were deposited in the uterus and in the Fallopian tube, with the exception of those animals showing the greatest delay, where tubal insemination resulted in fewer eggs being fertilized and in cleavage being more retarded.

It appears that the phenomenon of delayed fertilization resulting from the use of epididymal spermatozoa is not due to an abnormal rate of sperm migration, but to the need for an extended period of capacitation. The epididymal spermatozoa of some bucks required more than twice as much time for capacitation as that reported to be necessary for ejaculated spermatozoa. It is suggested that the process of sperm capacitation is primarily a continuation of the maturation process begun in the epididymis of the male.
\end{abstract}

\section{INTRODUCTION}

The acquisition of fertilizing capacity by spermatozoa during their passage through the male reproductive tract has been investigated in the guinea-pig (Young, 1931), rat (Blandau \& Rumery, 1961, 1964) and rabbit (Bedford, 1963, 1966; Orgebin-Crist, 1967, 1968). In the rabbit, it appears that spermatozoa begin to acquire fertilizing ability in the middle segment of the corpus epididymidis, but variable fertilization levels have been reported following insemination of spermatozoa from this segment (Bedford, 1966; Orgebin-Crist, 1967). Orgebin-Crist (1967) observed retarded cleavage in eggs fertilized by spermatozoa derived from all segments of the epididymis, the delay being most pronounced with spermatozoa obtained from the lower part of the corpus epididymidis. She suggested that retarded cleavage was related to delayed fertilization, this delay being due to a lowered ability of the epididymal spermatozoa to reach the site of fertilization and/or to establish contact with

$$
\text { * Postal address: } 307 \text { Huntingdon Road, Cambridge CB3 0JQ. }
$$


the eggs (Orgebin-Crist, 1968). The object of the present series of experiments was to re-investigate the question of delayed fertilization following insemination of epididymal spermatozoa with particular reference to sperm migration and capacitation.

\section{MATERIALS AND METHODS}

\section{Collection of epididymal spermatozoa}

The reproductive tracts of fifteen male rabbits of mixed breeds were removed at autopsy, the lower segment of the corpus epididymidis dissected as described by Orgebin-Crist (1967), and the tissue immersed in $1 \mathrm{ml}$ of acid saline (Hammond, 1949), composed of $\mathrm{NaCl}, 880 \mathrm{mg} \%$; KCl, $30 \mathrm{mg} \%$; $\mathrm{CaCl}_{2}, 25 \mathrm{mg} \%$; $\mathrm{MgCl}_{2}, 5 \mathrm{mg} \% ; \mathrm{NaH}_{2} \mathrm{PO}_{4}, 10 \mathrm{mg} \%$ in distilled water, to which $5 \%$ rabbit serum and $0.25 \%$ glucose had been added. The tissue was then minced with iridectomy scissors to release the spermatozoa into the saline and the sperm suspension was strained, using cotton gauze.

\section{Insemination of epididymal spermatozoa}

A total of forty cross-bred does was used, half of which were treated with a saline suspension of an acetone-extracted horse anterior pituitary preparation to induce superovulation (Pincus, 1940). All does were injected with 25 i.u. HCG to induce ovulation, which was assumed to take place $10 \mathrm{hr}$ later. Does were anaesthetized with pentobarbitone sodium and ether before insemination at laparotomy with suspensions of epididymal spermatozoa. Insemination took place at the time of HCG injection, or $5 \mathrm{hr}$ before, or $2 \mathrm{hr}$ after the injection. In the twenty-five does inseminated at the time of giving HCG or $2 \mathrm{hr}$ later, 5 to $20 \times 10^{6}$ spermatozoa were deposited into one uterine horn in $0.2 \mathrm{ml}$ of fluid, and 1 to $5 \times 10^{5}$ spermatozoa in $0.02 \mathrm{ml}$ were deposited into the contralateral Fallopian tube through the utero-tubal junction. The remaining fifteen does were inseminated into each uterine horn with 5 to $20 \times 10^{6}$ spermatozoa in $0.2 \mathrm{ml} 5 \mathrm{hr}$ before HCG in order that the spermatozoa, approaching the end of an 18-hr period of incubation in the female tract, would be in the presence of newly ovulated eggs, thus reducing the possibility of a low fertilization level due to egg non-viability.

\section{Recovery and examination of eggs}

From those does which were inseminated within $2 \mathrm{hr}$ of the HGG injection, eggs were recovered by flushing the tubes with physiological saline either in vivo or at autopsy 27 to $30 \mathrm{hr}$ later. In order to determine the fertilizing capacity of epididymal spermatozoa $18 \mathrm{hr}$ after insemination, eggs were recovered approximately $3 \mathrm{hr}$ after ovulation before egg viability declined. These newly penetrated eggs were cultured for $24 \mathrm{hr}$ in $20 \%$ serum acidic saline at $37^{\circ} \mathrm{C}$ to permit a more accurate assessment of fertilization levels.

All the recovered eggs were mounted on a glass slide and examined by phase contrast microscopy for evidence of polar bodies, pronuclei and cleavage. After fixation for 20 to $24 \mathrm{hr}$ in acetic alcohol and staining in $1 \%$ lacmoid, they were re-examined in order to obtain more detailed evidence of fertiliza- 
tion. The number of spermatozoa in eggs was also noted, separate counts being made of those spermatozoa in contact with the zona pellucida and those present in the perivitelline space.

\section{RESULTS}

The fertilizing ability of sperm samples obtained from the lower corpus epididymidis of individual bucks varied greatly (Table 1). On the other hand,

\section{TABLE 1}

FERTILIZATION FOLLOWING INSEMINATION OF SPERMATOZOA FROM THE LOWER CORPUS EPIDIDYMIDIS (EGG RECOVERY AT 27 TO 30 HR FOLLOWING INSEMINATION AND HGG INJECTION)

\begin{tabular}{|c|c|c|c|c|c|c|c|c|c|}
\hline \multirow[b]{2}{*}{$\begin{array}{c}\text { Buck } \\
\text { no. }\end{array}$} & \multirow{2}{*}{$\begin{array}{c}\text { No. of } \\
\text { does } \\
\text { inseminated }\end{array}$} & \multirow{2}{*}{$\begin{array}{l}\text { No. of } \\
\text { eggs } \\
\text { recovered }\end{array}$} & \multirow{2}{*}{$\begin{array}{c}\text { No. of } \\
\text { eggs un- } \\
\text { fertilized }\end{array}$} & \multicolumn{5}{|c|}{ Stage of egg development } & \multirow{2}{*}{$\begin{array}{l}\text { Mean no } \\
\text { of sperm. } \\
\text { per egg* }\end{array}$} \\
\hline & & & & Pronuclear & $\begin{array}{l}\text { Fertilized } \\
\text { (uncleaved) }\end{array}$ & 2-cell & $\begin{array}{l}\text { 3- to } \\
\text { 4-cell }\end{array}$ & $\begin{array}{l}\text { 6- to } \\
\text { 8-cell }\end{array}$ & \\
\hline $\begin{array}{r}1 \\
2 \\
3 \\
4 \\
5 \\
6 \\
7 \\
8 \\
9 \\
10\end{array}$ & $\begin{array}{l}2 \\
4 \\
2 \\
2 \\
3 \\
2 \\
2 \\
2 \\
2 \\
3\end{array}$ & $\begin{array}{l}22 \\
72 \\
21 \\
14 \\
27 \\
21 \\
13 \\
33 \\
34 \\
26\end{array}$ & $\begin{array}{r}18 \\
45 \\
8 \\
6 \\
3 \\
2 \\
1 \\
2 \\
1 \\
0\end{array}$ & $\begin{array}{l}0 \\
6 \\
4 \dagger \\
0 \\
3 \\
2 \\
0 \\
1 \\
0 \\
0\end{array}$ & $\begin{array}{l}0 \\
2 \\
7 \\
0 \\
0 \\
0 \\
0 \\
0 \\
0 \\
0\end{array}$ & $\begin{array}{r}4 \\
13 \\
2 \\
7 \\
7 \\
14 \\
5 \\
16 \\
4 \\
15\end{array}$ & $\begin{array}{r}0 \\
6 \\
0 \\
1 \\
12 \\
3 \\
7 \\
14 \\
25 \\
11\end{array}$ & $\begin{array}{l}0 \\
0 \\
0 \\
0 \\
0 \\
0 \\
0 \\
0 \\
4 \\
0\end{array}$ & $\begin{array}{r}0 \cdot 35 \\
1 \cdot 24 \\
2 \cdot 30 \\
2.67 \\
3 \cdot 18 \\
1 \cdot 52 \\
18 \cdot 10 \\
4.67 \\
5 \cdot 56 \\
13 \cdot 10\end{array}$ \\
\hline
\end{tabular}

The bucks are arranged in order of increasing fertility.

* Includes the fertilizing spermatozoon and all spermatozoa observed in the perivitelline space or in contact with the zona pellucida.

$\dagger$ Of these four eggs, three contained three pronuclei.

TABLE 2

FERTILIZATION FOLLOWING INSEMINATION OF SPERMATOZOA FROM THE LOWER CORPUS EPIDIDYMIDIS AT THE TIME OF, OR 2 HR AFTER, HCG INJEGTION

\begin{tabular}{c|ccc|c|c}
\hline $\begin{array}{c}\text { Time of } \\
\begin{array}{c}\text { insemination } \\
\text { relative to } \\
\text { HCG }\end{array}\end{array}$ & $\begin{array}{c}\text { No. of } \\
\text { does } \\
\text { inseminated }\end{array}$ & $\begin{array}{c}\text { No. of } \\
\text { eggs } \\
\text { recovered }\end{array}$ & $\begin{array}{c}\text { No. of } \\
\text { eggs } \\
\text { cleaved }\end{array}$ & $\begin{array}{c}\text { Proportion } \\
\text { of eggs } \\
\text { fertilized } \\
(\%)\end{array}$ & $\begin{array}{c}\text { Mean } \\
\text { no. of } \\
\text { sperm. } \\
\text { per egg }\end{array}$ \\
\hline $\begin{array}{c}0 \mathrm{hr} \\
+2 \mathrm{hr}\end{array}$ & 10 & 80 & 58 & $72 \cdot 5$ & $6 \cdot 11$ \\
\hline
\end{tabular}

little variation in fertilization levels was observed irrespective of whether spermatozoa from the same sample were deposited at the time of HCG injection or $2 \mathrm{hr}$ later (Table 2). Similarly, with the majority of the sperm samples, the site of sperm deposition, whether in the uterus or the Fallopian tube, appeared to be of little consequence so far as fertilization level was concerned. However, in those cases where fertilization was lowest, the majority of the unfertilized eggs 
were recovered from the side of the tract where spermatozoa had been deposited in the tube (Table 3). When does were inseminated with epididymal spermatozoa $5 \mathrm{hr}$ before HCG injection, $39 \%$ of the eggs recovered $3 \mathrm{hr}$ after ovulation showed evidence of fertilization following $24 \mathrm{hr}$ in culture. In a control group of sixty-three eggs recovered $13 \mathrm{hr}$ p.c. and cultured under similar conditions, $87 \%$ proved to be fertilized (Table 4 ).

\section{TABLE 3}

FERTILIZATION FOLLOWING INSEMINATION OF EPIDIDYMAL SPERMATOZOA FROM BUCKS 1,2 AND 3 INTO THE UTERUS AND CONTRALATERAL TUBE OF REGIPIENT DOES. EGGS RECOVERED 27 TO 30 HR AFTER INSEMINATION AND HGG INJECTION

\begin{tabular}{l|ccc|c|c}
\hline $\begin{array}{c}\text { Site of } \\
\text { insemination }\end{array}$ & $\begin{array}{c}\text { No. of } \\
\text { does } \\
\text { inseminated }\end{array}$ & $\begin{array}{c}\text { No. of } \\
\text { eggs } \\
\text { recovered }\end{array}$ & $\begin{array}{c}\text { No. of } \\
\text { eggs } \\
\text { fertilized }\end{array}$ & $\begin{array}{c}\text { Proportion } \\
\text { of eggs } \\
\text { fertilized } \\
(\%)\end{array}$ & $\begin{array}{c}\text { Mean } \\
\text { no. of } \\
\text { sperm. } \\
\text { per egg }\end{array}$ \\
\cline { 1 - 5 } & 8 & 58 & 6 & 10 & $10 \cdot 2$ \\
$\begin{array}{l}\text { Fallopian tube } \\
\text { Uterus }\end{array}$ & 8 & 58 & 38 & 66 & $11 \cdot 5$ \\
\hline
\end{tabular}

TABLE 4

FERTILIZATION FOLLOWING UTERINE INSEMINATION OF SPERMATOZOA FROM THE LOWER CORPUS EPIDIDYMIDIS 18 HR BEFORE EGG RECOVERY. EGGS WERE RECOVERED 3 HR AFTER OVULATION AND GULTURED in vitro FOR 24 HR. CONTROL EGGS WERE RECOVERED FOR GULTURE 13 HR P.C.

\begin{tabular}{|c|c|c|c|c|c|c|c|c|}
\hline \multirow{2}{*}{$\begin{array}{c}\text { Buck } \\
\text { no. }\end{array}$} & \multirow{2}{*}{$\begin{array}{c}\text { No. of } \\
\text { does } \\
\text { inseminated }\end{array}$} & \multirow{2}{*}{$\begin{array}{l}\text { No. of } \\
\text { eggs } \\
\text { recovered }\end{array}$} & \multirow{2}{*}{$\begin{array}{l}\text { No. of } \\
\text { eggs un- } \\
\text { fertilized }\end{array}$} & \multicolumn{4}{|c|}{ Stage of egg development } & \multirow{2}{*}{$\begin{array}{l}\text { Mean no. } \\
\text { of sperm. } \\
\text { per egg }\end{array}$} \\
\hline & & & & $\begin{array}{l}2- \\
\text { cell }\end{array}$ & $\begin{array}{c}\text { 3- to } 4- \\
\text { cell }\end{array}$ & $\begin{array}{c}\text { 6- to 8- } \\
\text { cell }\end{array}$ & Fragmented & \\
\hline $\begin{array}{l}11 \\
12 \\
13 \\
14 \\
15\end{array}$ & $\begin{array}{l}2 \\
4 \\
4 \\
2 \\
3\end{array}$ & $\begin{array}{r}9 \\
61 \\
14 \\
33 \\
13\end{array}$ & $\begin{array}{r}9 \\
50 \\
2 \\
0 \\
1\end{array}$ & $\begin{array}{l}0 \\
0 \\
1 \\
0 \\
0\end{array}$ & $\begin{array}{r}0 \\
0 \\
6 \\
23 \\
0\end{array}$ & $\begin{array}{r}0 \\
0 \\
1 \\
7 \\
12\end{array}$ & $\begin{array}{r}0 \\
11 \\
4 \\
3 \\
0\end{array}$ & $\begin{array}{l}1 \cdot 00 \\
0 \cdot 61 \\
2 \cdot 00 \\
1 \cdot 85 \\
2 \cdot 30\end{array}$ \\
\hline Control & 10 & 63 & 6 & 7 & 32 & 16 & 2 & - \\
\hline
\end{tabular}

\section{DISCUSSION}

Individual bucks differed widely in fertility as measured by fertilization levels observed after insemination of spermatozoa from the same segment of the epididymis. Thus, in eight out of the total of fifteen bucks, the spermatozoa obtained from the lower corpus epididymidis fertilized over $80 \%$ of eggs in recipient does while in the remaining seven, the fertilization levels ranged from 0 to $64 \%$. By comparison with the normal rate of cleavage following fertilization with ejaculated spermatozoa (Gregory, 1930; Adams, 1956; Orgebin-Crist, 1967), the use of epididymal spermatozoa from all bucks, except one, resulted in retarded cleavage of eggs, confirming the observations of Orgebin-Crist $(1967,1968)$. 
Evidence that the retardation in cleavage resulted from a delay in fertilization is provided by the following observations: low levels of fertilization, failure of a high proportion of fertilized eggs to cleave, polyspermy, and low penetration rates of freshly ovulated eggs in the presence of spermatozoa resident in the female tract for the previous $18 \mathrm{hr}$. Except in those pronuclear eggs in which cleavage failed to occur, there was no evidence that the observed retardation was due to arrested development.

Insemination into the tubes did not raise the level of fertilization. In fact, in those animals where fertilization was most delayed, tubal insemination resulted in fewer eggs being fertilized and cleavage being more retarded, although sperm numbers in recovered eggs were about the same.

The present results suggest that delayed fertilization following insemination of epididymal spermatozoa is not related to abnormal sperm migration but rather to extended capacitation requirements, epididymal spermatozoa taking longer to capacitate than ejaculated spermatozoa. That differences in levels of

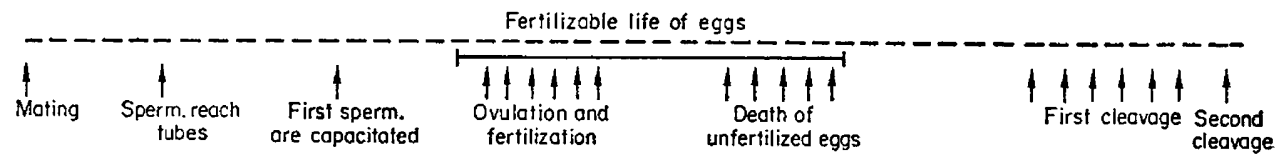

(o)

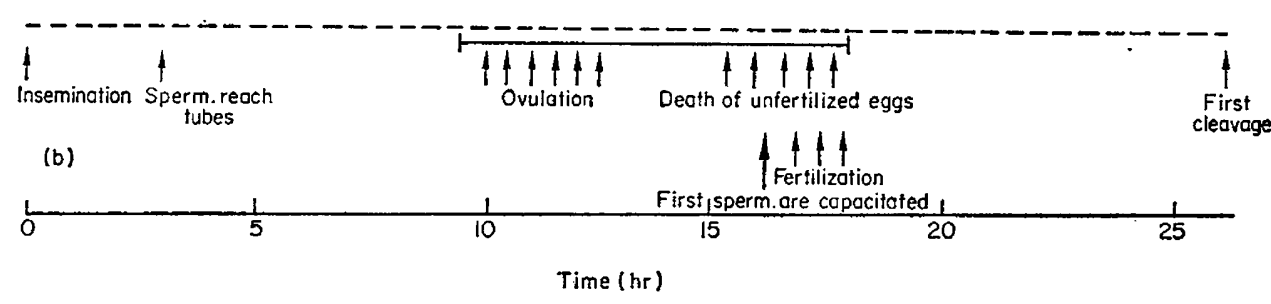

TExT-Fig. 1. Postulated sequence of events following (a) natural mating and (b) insemination of epididymal spermatozoa: extended capacitation requirements result in fewer eggs fertilized and delayed cleavage.

fertilization following contralateral uterine and tubal insemination were observed only when cleavage was extremely delayed, indicates the limitations of the in vivo capacitation test system for determining variability in the capacitation requirements of different sperm populations. Differences in capacitation time of 3 or $4 \mathrm{hr}$ may go unnoticed owing to even greater variations in ovulation time and egg life in recipient animals. According to Bedford (1967a), capacitation is a multi-phase process, the first stage of which is normally accomplished in the uterus and the final stage in the tube. The entire process normally requires 6 to $7 \mathrm{hr}$ but may take 3 to $4 \mathrm{hr}$ longer in the tube alone (Adams \& Chang, 1962). It appears that the epididymal spermatozoa of some bucks required more than twice the normal period of capacitation in the uterus and tube; while capacitation of spermatozoa deposited directly into the contralateral tube was even further delayed, thus leading to still lower fertilization levels (Text-fig. 1). Similarly, in eggs recovered $3 \mathrm{hr}$ after ovulation, by which time fertilization has normally occurred (Pincus, 1939), the epididymal 
spermatozoa of two bucks had not penetrated even though they were inseminated $18 \mathrm{hr}$ earlier. Under similar conditions, spermatozoa from the corresponding segment of the tracts of two other bucks fertilized over $90 \%$ of the eggs.

The ligation experiments of Gaddum \& Glover (1965) and Bedford (1967b) indicate that specific regions of the male tract do not play a direct role in sperm maturation. The present work suggests that, in individuals, epididymal sperm populations mature at different rates, some bucks having more mature spermatozoa in a given segment of their epididymis than others. The persistence of these individual differences at ejaculation could result in differential capacitation requirements, suggested by Adams \& Chang (1962) and again by Dziuk (1965) as a possible mechanism in selective fertilization.

That these differences in maturity may be 'compensated for' by a longer sojourn in the female tract indicates a close relationship between the physiological processes of sperm maturation in the male reproductive tract and capacitation in the female tract. The evidence available from the present experiments lends support to the view that sperm capacitation is primarily a continuation of the maturation process, begun in the epididymis of the male.

\section{ACKNOWLEDGMENTS}

Acknowledgment is made to Dr C. E. Adams and Professor T. R. R. Mann, F.R.s., for reading and criticizing this manuscript, and to Mr M. L. Norris for technical assistance. The author was supported by a Fulbright Scholarship awarded by the United States-United Kingdom Education Commission.

\section{REFERENCES}

AdAms, C. E. (1956) A study of fertilization in the rabbit: the effect of post-coital ligation of the Fallopian tube or uterine horn. F. Endocr. 13, 296.

Adams, C. E. \& Chang, M. C. (1962) Capacitation of rabbit spermatozoa in the Fallopian tube and in the uterus. F. $\exp$. Zool. 151, 159.

Bedford, J. M. (1963) Morphological changes in rabbit spermatozoa during passage through the epididymis. 7. Reprod. Fert. 5, 169.

Bedford, J. M. (1966) Development of fertilizing ability of spermatozoa in the epididymis of the rabbit. F. exp. Zool. 163, 319.

BEDFORD, J. M. (1967a) Experimental requirement for capacitation and observations on ultrastructural changes in rabbit spermatozoa during fertilization. F. Reprod. Fert. Suppl. 2, 35.

BEDford, J. M. (1967b) Effects of duct ligation on the fertilizing ability of spermatozoa from different regions of the rabbit epididymis. F. exp. Zool. 166, 271.

Blandau, R. J. \& Rumery, R. E. (1961) Fertilizing capacity of rat spermatozoa recovered from various segments of the epididymis. Anat. Rec. 139, 202.

Blandau, R. J. \& Rumery, R. E. (1964) The relationship of swimming movements of epididymal spermatozoa to their fertilizing capacity. Fert. Steril. 15, 571.

Dziuk, P. V. (1965) Double mating of rabbits to determine capacitation time. F. Reprod. Fert. 10, 389.

Gaddum, P. \& Glover. T. D. (1965) Some reactions of rabbit spermatozoa to ligation of the epididymis. F. Reprod. Fert. 9, 119.

Gregory, P. W. (1930) The early embryology of the rabbit. Contr. Embryol. 21, 141.

HAMmond, J., JR (1949) Recovery and culture of tubal mouse ova. Nature, Lond. 163, 28.

Orgebin-CRIST, M. C. (1967) Maturation of spermatozoa in the rabbit epididymis: fertilizing ability and embryonic mortality in does inseminated with epididymal spermatozoa. Annls Biol. anim. Biochim. Biophys. 7, 373.

ORGEBIN-CRIST, M. C. (1968) Maturation of spermatozoa in the rabbit epididymis: delayed fertilization in does inseminated with epididymal spermatozoa. F. Reprod. Fert. 16, 29. 
Pincus, G. (1939) The comparative behavior of mammalian eggs in vivo and in vitro. IV. The development of fertilized and artificially activated eggs. F. exp. Zool. 82, 85.

Pincus, G. (1940) Superovulation in rabbits. Anat. Rec. 77, 1.

Younc, W. C. (1931) A study of the function of the epididymis. III. Functional changes undergone by spermatozoa during their passage through the epididymis and vas deferens in the guinea pig. 7. exp. Biol. 8, 151. 